\title{
Experiences of New Teachers in Inclusive Classrooms in BC
}

\author{
Jessie Moore and Jillian Roberts \\ University of Victoria
}

\begin{abstract}
Current research states the need for special education training for preservice teachers; however, research examining best practice in special education training is limited due to a focus on preservice teachers and a lack of Canadian research. This phenomenologically informed study explores the experiences of new teachers in inclusive classrooms to gain an understanding of the knowledge and experiences these new teachers need so as to inform future teacher training practices. The participants include seven new teachers who teach in inclusive classrooms across British Columbia. Results indicate that due to the student diversity in their inclusive classrooms, these new teachers collaborated with colleagues, parents, and students to meet the academic, social, and behavioural needs of their students. Based on these new teachers' experiences, initial recommendations are provided for teacher training institutions. Directions for further research are also discussed.
\end{abstract}

The British Columbia (BC) Ministry of Education (2001) states that the "goal of the BC school system is to support the . . . development of all students, including those with special needs" (Special Education, para. 1). This has not always been a goal of the BC education system; over the past hundred years, there has been a progressive shift from students with special needs be- 
ing excluded from schools to individualized education in the least restrictive environment for all students (Andrews \& Lupart, 2000). This shift has led to a school system that has adopted the principles of inclusion (BC Ministry of Education, 2001). Currently, the BC school system utilizes an inclusive framework that results in general education teachers teaching special needs students within inclusive classrooms. The BC School Act states that it is a teacher's responsibility to design, supervise, and assess individual educational programs for all students (BC Ministry of Education, 1996). As a result, "teaching is an increasingly complex and demanding profession ... [as] classrooms are more diverse than in the past" (Alberta's Commission on Learning, 2004, Excellent teachers and school leaders, para. 5).

Despite teachers' responsibilities in giving instruction and overseeing the educational programs of students with special needs, Naylor (2002) found that over half of the respondents from a representative BC school district did not feel prepared to work with their students with special needs. Subsequently, Naylor (2004) discovered similar results with two other school districts in BC. "Over $40 \%$ of respondents in both Nanaimo and Coquitlam stated that they felt professionally unprepared to teach students with special needs" (Teacher views on training and practice, para. 1).

In a 1999 review of age demographics of teachers in $\mathrm{BC}, 47 \%$ of teachers were over the age of 44, with most of these teachers expected to retire by the year 2014 (BC Ministry of Finance and Corporate Relations, 2000). This situation will see a projected replacement of almost half of BC's experienced teachers with new teachers entering the workforce. In order for new teachers to feel confident to address diverse learning needs, teacher training institutions must prepare future teachers for inclusive classrooms. Cook (2002) argues that if preservice teachers do not gain experience, knowledge, and skills surrounding children with special needs in training programs, children in future classes will have a decreased opportunity to succeed.

The idea of focusing on teacher education programs to better prepare teachers is echoed throughout the literature, including major stakeholders in the education system: (a) researchers, (b) Ministry of Education, (c) practicing teachers, and (d) parents (BC Confederation of Parent Advisory Councils, 1999; BC Ministry of Education, 2000; Brownell, Ross, Colon, \& McCallum, 2005; Cook, 2002; Davern, 1999; Lombardi \& Hunka, 2001; Naylor, 2002; Strawderman \& Lindsey, 1995).

Current literature presents mixed results about programs including special education training in a generalist teacher education program; several re- 
searchers have found that programs either lack a focus on special education training or lack any special education training at all (Bondy, Ross, Sindelar, \& Griffin, 1995; Brownell et al., 2005; Wigle \& Wilcox, 1996). In BC, all teacher education institutions must ensure their graduates meet uniform standards as mandated by the (BCCT; BC College of Teachers, 2004). Despite these uniform standards, there is tremendous variety in how special education training is operationalized including required coursework; optional certificates, strands, and minors; and practicum experiences (Malaspina University College, 2004; Simon Fraser University, 2004; Trinity Western University, 2004; University of British Columbia, 2004; University College of the Cariboo, 2004; University of Northern British Columbia, 2004; University of Victoria, 2003). Naylor (2004) comments on this variety by stating that "it is still possible to graduate from some teacher training programs in $\mathrm{BC}$ without having taken units about teaching to exceptionalities. Even in institutions where units exist and are mandatory, the focus is limited and arguably insufficient" (Teacher views on Training and Practice, para. 1).

Extant literature examining best practice in special education training is limited due to the focus on preservice teachers as subjects and a lack of research done in BC. Current research uses preservice teachers as informants for effective preservice curriculum (Hamre \& Oyler, 2004; Lombardi \& Hunka, 2001; Werts, Mamlin, \& Pogoloff, 2002). It is important that informants of special education training for generalist teachers have had experience working within inclusive classrooms (Brownell et al., 2005; Hamre \& Oyler, 2004; Whitaker, 2003).

Extant literature is also limited due to a lack of research done in BC. The majority of studies in the area of informing preservice special education training are written by researchers from the United States (Billingsley \& Tomchin, 1992; Kilgore \& Griffin, 1998; Whitaker, 2000, 2003). Welch (1996) describes the "dual" system of general education and special education that exists; teachers are trained as either general educators or special educators in preservice teacher training. Currently, according to the BC Ministry of Education (2000), the $\mathrm{BC}$ school system utilizes an inclusive framework that results in general education teachers teaching special needs students within an inclusive classroom.

Due to the lack of research done in $\mathrm{BC}$ and the exclusion of new teachers as subjects in extant research, there is a need to examine the experiences of new teachers in inclusive classrooms in $\mathrm{BC}$ in order to highlight the needs of these new teachers. This will begin to raise an awareness of effective teacher training practices. New teachers can offer insights into their experiences in 
inclusive classrooms while also providing valuable information about the most effective practice of special education training that would have prepared them for the reality of inclusion. The following questions guided the research:

1. What are the lived experiences of new teachers in inclusive classrooms?

2. Based on their lived experiences in inclusive classrooms, what recommendations can these new teachers offer to teacher training institutions about effective special education training for preservice teachers?

\section{Methodology}

A qualitative approach was used to investigate the experiences of a sample of new teachers in inclusive classrooms. Consistent with the research question of exploring the experiences of new teachers, the author used a phenomenological research design in order to investigate individuals' lived experiences (Creswell, 1998; Moustakas, 1994; Patton, 1990, Polkinghorne, 1989). Patton (1990) states that "phenomenological inquiry focuses on the question: 'what is the structure and essence of experience of this phenomenon for these people?"' (p. 69). By studying the essence, or underlying structure, of experience of a sample of new teachers in inclusive classrooms, an awareness of what knowledge and experiences these new teachers need will help to inform future preservice special education training practices.

\section{Participants}

Participants were selected on the basis that they met the following definition of a new teacher: new teachers have had their first full-time teaching contract within the last five years. These new teachers were also working in the BC public school system. Consistent with the phenomenological approach of "studying a small number of subjects" (Creswell, 2003, p. 15), the author included 7 participants that met the criteria and constituted a diverse range of new teachers in BC. There were 6 female participants and 1 male participant. The researcher included new teachers from a variety of locations in order to represent the diversity of teaching situations that exist in $\mathrm{BC}$, including rural and urban schools, as well as schools with students from a range of socio-economic statuses. A range of grade levels was also taken into consideration, from Kindergarten through Grade 8. The author hoped to uncover the essence of experience for new teachers regardless of teaching location and grade level. 
While the participants had varied life experiences and training, they were consistent with their views regarding the goals of education. These uniform views fit within the BC Ministry of Education (2006) goal of education which states that "all [italics added] students should have equitable access to learning, opportunities for achievement, and the pursuit of excellence in all aspects of their educational programs" (Special Education, para. 1). Each participant described their role as a teacher in an inclusive classroom within the role of a teacher as outlined by the BC School Act (BC Ministry of Education, 1996).

\section{Data Collection and Analysis}

Interviews with participants were used as a way of investigating the research questions of the study. There were two interviews for each participant. Each interview followed a semi-structured interview protocol and, as recommended by Seidman (1998), was tape-recorded for the author to later review. Brantlinger et al. (2005) discusses that using an interview protocol with flexibility is important "so that questions may be modified or added to as preliminary evidence emerges" (p. 198). The author used questions from the interview protocol to begin discussion of the topic, to maintain conversational flow, as well as to redirect the discussion to the topic of interest. It was the author's goal that each subject was free to describe their experience in inclusive classrooms as they felt the experience should be described. The semi-structured format allowed flexibility within the interview to allow the participants to discuss their own experiences, while also providing consistency to the interviews in ensuring participants were asked the same questions.

The procedure used for data analysis was informed by Colaizzi (1978) and Roberts and Cairns (1999). Consistent with the work of Roberts and Cairns, after all interviews were transcribed, the author read and reread each transcript in order to gain an understanding of the overall meaning of each interview. Following this, the author extracted significant statements from each of the transcripts and then formulated themes from these extracted statements. The author then sent the transcript as well as the listing of themes to each participant for verification. After all participants had verified the transcripts and initial analyses, a second telephone interview with each participant took place. The second interview served to provide a deeper understanding of the new teachers' experiences. Data analysis for the second interviews followed the same format as for the first interviews, with the result being a complete listing of themes for each participant. Listings of themes along with their supporting statements for each participant were typed and printed using a different font in order to visually track common themes across participants. The author cut up 
the themes with the supporting statements from each interview and grouped them according to their central meaning. After groups had been made, only two themes from individual participants were left over. One of these leftover themes was 'lack of consistent school hours.' This participant described his experience in an isolated school that faced repeated closures due to power outages, road closures, and extreme weather. The leftover themes were later analyzed in the context of the analysis and the author determined they were not appropriate to the larger context. The theme groupings that resulted contained support from at least three of the participants. Theme groupings were then labeled and supporting statements for each theme were organized into folders. Following, the author grouped the theme folders into related clusters. Each cluster was labeled according to its central meaning and was colour coded. Finally, the author grouped clusters into categories. These categories were labeled according to their central meaning and included: (a) student diversity, (b) collaboration, and (c) curriculum. An outline of these categories and clusters is provided in Table 1 . The categories, clusters, and themes that resulted were used to describe the essential essence of the experience of the new teachers in their inclusive classrooms. This description, along with the categories, clusters, and themes were sent to participants for final verification.

\section{Results}

\section{Essential Essence of the Experience}

Participants shared many positive experiences about their teaching, but there were also some frustrations and challenges. Due to the diversity of students in their inclusive classrooms, participants relied on collaboration with colleagues, parents, and students to meet curricular outcomes, including an informal alternative curriculum that resulted from the social and behavioural needs of the students in their classrooms. Based on their experiences in their inclusive classrooms, participants had several recommendations to offer.

\section{Category One: Student Diversity}

Participants described the tremendous diversity present in their classrooms. The themes that comprise these clusters are outlined in Table 2. A discussion of the clusters that comprised this category will include examples of themes and supporting participant quotations. 
Table 1

Categories and Clusters

Categories

\begin{tabular}{ccc}
\hline Student Diversity & Collaboration & Curriculum \\
\hline & Clusters within each Category & \\
\hline $\begin{array}{c}\text { Range of Ability } \\
\text { Not Meeting Ministry } \\
\text { Designations }\end{array}$ & Collaboration with Colleagues & Alternative Curriculum \\
& Parental Considerations & Adaptations \\
\hline
\end{tabular}

Table 2

Category One: Student Diversity

\begin{tabular}{cc}
\hline \multicolumn{2}{c}{ Clusters } \\
\hline Range of Ability & Not Meeting Ministry Designations \\
\hline $\begin{array}{c}\text { Focus on Lower Achieving Students } \\
\text { Not Meeting the Needs of Higher } \\
\text { Achieving Students }\end{array}$ \\
\hline
\end{tabular}

\section{Cluster One: Range of Ability}

The themes that comprised this category were (a) Focus on Lower Achieving Students and (b) Not Meeting the Needs of Higher Achieving Students. Participants described the wide range of ability of students in their inclusive classrooms. Participants shared a concern that most of their time was spent with their "struggling" (Julie) or lower achieving students. These lower achieving students struggled both academically and behaviourally. Participants discussed their awareness of the disproportionate time they spent with their 
struggling students; however, this did not change their focus. Amy stated that "you want to make sure that you are not focusing all of your time on [the struggling] kids . . . but you need more time because you have to help out everyone else in your class too."

Due to their heightened focus on lower achieving students, participants felt they were frequently not able to meet the needs of their higher achieving students. Some of these students had "gifted" designations and others were not designated but were achieving above grade level expectations. "I had two gifted students and after the year was over I felt bad that I couldn't help them as much as I now know I could have helped" (Trisha).

\section{Cluster Two: Not Meeting Ministry Designations}

Participants expressed their frustrations with struggling students in their classrooms who did not meet Ministry designation guidelines and therefore did not qualify to be considered as having special needs. These students were referred to as "grey area" (Amy) students. This cluster was comprised of one theme: Grey Area Students.

The BC Ministry of Education defines these students as those who are not designated as having a special need but who are struggling with meeting their grade level curricular expectations (BC Ministry of Education, Skills and Training, 1997). Amy was concerned about one of her students that had recently lost his Ministry designation:

This kid is the poster child for grey area children. He was designated LD (Learning Disabled) in elementary school. Then he was reassessed this year and he lost his LD designation because there isn't the discrepancy anymore but he wasn't low enough for M-ID [Moderate Intellectual Disability]... . Right now, we are doing what we can to make it work for this kid, but next year unless someone does more than they should or takes him under their wing, he may drop out.

\section{Category Two: Collaboration}

As a result of the student diversity in their classrooms, participants spoke of how they collaborated with colleagues, students, and parents to help meet the learning needs of the students in their inclusive classrooms. The themes that make up these clusters are described in Table 3. A discussion of the clusters that comprised this category will include examples of themes and supporting participant quotations. 
Table 3

Category Two: Collaboration

Clusters

Collaboration with Colleagues Parental Considerations Student Collaboration

Mentoring Parental Support Classroom Community

IEP Teams Challenges with Parents Peer Tutoring

Teacher Assistant Support

Students as Experts

\section{Cluster One: Collaboration with Colleagues}

Throughout the interviews, participants described how they collaborated with other teachers to best meet the diverse needs of the learners in their classes. This cluster is comprised of the following themes: (a) Mentoring, (b) IEP Teams, and (c) Teacher Assistant Support. Participants discussed their lack of experience in meeting their students' diverse needs and explained how they learned from others with experience. Participants also shared the value of collaboration with members of a child's IEP team and the teacher assistants (TAs) that were assigned to work with students with special needs.

I have a Grade three student who is reading at a Kindergarten level. He didn't even have all of his letter sounds. I worked with the [teacher] assistant and she has been able to give him individual reading practice daily and now he is reading at a mid Grade one level. (Ruby)

\section{Cluster Two: Parental Considerations}

Throughout their interviews, participants described the importance of collaborating with the parents. Participants spoke of both the support and encouragement parents offered, as well as some challenges they faced with parents. This cluster contains two themes: (a) Parental Support and (b) Challenges with Parents.

Participants reported that collaboration with parents was an effective way to learn about their students' needs and support their students' educational programs. Participants discussed how parental support varied with each student. 
Amy noted that some parents showed a great deal of support, whereas others posed many challenges. "The support level and the ideas of every parent are different and some parents have lots of support for teachers and education and some don't at all." Trisha commented that "a lot of parents were ... supportive if you gave them a call and said this is what is happening, or you kind of touch base and you let them come in as much as they can to help you out and ask you what's going on, what they can do at home." Amy discussed the challenges in providing realistic expectations to parents about their child's abilities:

I mean some parents want you to promise them the world as a teacher and you want as a teacher to give them that piece of mind that their child will be taken care of and you do take care of them and help them out as much as you can, but at the same time, you need to make sure that everybody has a realistic view of everything and of what those capabilities are of the particular students and the ideologies of inclusion and that sort of the thing and how it works and how it doesn't work.

\section{Cluster Three: Student Collaboration}

During interviews, participants described how they collaborated with the students in their classrooms to meet students' unique needs. The following themes describe the types of student collaboration in the inclusive classrooms: (a) Classroom community, (b) Peer tutoring, and (c) Students as experts. Participants described how they encouraged the students to create a community of learners in their classrooms with students and the teacher learning together about learning and teaching practices. The collaboration that occurred within each of the participant's classrooms led to improvements in individual as well as whole class behaviours. Catherine explained how she created a sense of community in her classroom:

I really emphasized that when they were loud or obnoxious during sit down work, that I took the focus off myself and made it that they were disrupting their classmates and that certain kids needed certain learning environments to understand stuff.

Participants perceived that one of the benefits of having a sense of community in the class was the willingness of the students to engage in peer tutoring. Julie commented on how she alternated between partners of similar ability levels so that "they get that extra challenge from each other," with partners of different ability levels able to "coach and teach each other."

Regardless of the age of their students, participants explained how they collaborated with their students to learn how to best meet their students' individ- 
ual needs. Often, the students were aware of their own needs and abilities and were able to work with their teachers to create effective learning strategies.

Due to the diverse needs in inclusive classrooms, participants collaborated with colleagues, parents, and their students. This collaboration was beneficial in supporting the range of learning needs in the inclusive classrooms and provided the new teachers with strategies to address curriculum considerations.

\section{Category Three: Curriculum}

Participants shared their knowledge of the Ministry prescribed learning outcomes; however, they explained that in order to address the social and behavioural needs of their students, they also followed an informal alternative curriculum, including social skills and behaviour management. This category is made up of two clusters: (a) Alternative Curriculum and (b) Adaptations. The themes that structure each cluster are illustrated in Table 4. Participant quotations will be used to enhance the meaning of each theme.

\section{Cluster One: Alternative Curriculum}

Despite having a prescribed curriculum with a primary focus on academic learning outcomes, participants described how they followed an informal alternative curriculum that centered on social and behavioural goals. This cluster contains two themes: (a) Social Needs and (b) Behavioural Considerations.

Table 4

Category Three: Curriculum

Clusters

Alternative Curriculum $\quad$ Adaptations

Social Needs

Individualized Instruction

Behavioural Considerations

Alternative Assessment

Challenges With Adaptations 
Due to the social needs of students in their classrooms, participants described how they focused on developing social skills for students. The new teachers perceived that developing appropriate social skills was more of a priority than achieving academic goals.

I found a lot of times during the day were more focused on the emotional issues and how to behave in the classroom like social skills, rather than academic. I found that it was hard to fit in the academic stuff when there was so much social skills that needed to be built . . . I feel that my academic things may have suffered somewhat. (Laura)

Throughout their interviews, the new teachers shared their experiences with behaviour management in their inclusive classrooms. Laura shared her reality of diverse classroom management strategies:

You had to make sure that those kids with behavioural problems weren't disrupting and interfering with the other children's learning as well so you had to come up with different behavioural strategies and it was different for every child as well, so something that worked very well for one child didn't work well for someone else so you had to make sure you had plans in place for all the children.

\section{Cluster Two: Adaptations}

In order to accommodate their students' diverse needs, participants perceived the need to adapt the curriculum. The themes that comprise this cluster are (a) Individualized Instruction, (b) Alternative Assessments, and (c) Challenges with Adapting the Curriculum.

Participants shared how they created individualized instruction for their students with unique learning needs. The new teachers planned their individualized instruction before the lessons, focused on individual students during instruction, and gave individualized instruction after whole class instruction. Amy described how she took her students' needs into consideration in her lesson planning:

When I plan my lessons I make sure that I am thinking about all of my students so that the kids that I have with learning disabilities and the kids who are on adapted programs I need to make their work a little bit different but still kind of following along with the rest of the class maybe according to what adaptations they need.

Participants explained their role of assessing the educational programs of the students in their classrooms. The new teachers described the alterna- 
tive assessments they created for struggling students. Catherine explained how a struggling student did not want to write anything in her class because he had not been successful in previous school years. "He went from a kid who wouldn't write anything to a kid that would hand in a whole page of writing because I told him I didn't care about spelling because he could not spell at all. I learned [Bob] writing."

Participants discussed their frustrations with the amount of adaptations that were required to address the diverse needs in their classrooms. "Every single child is so individual and has different needs and different things that are challenging for them and different things they need to work on" (Laura). Amy was frustrated with the amount of adaptations she had to make to her assignments along with the adaptations to the assessment that went with it. "I am aware of the adaptations required for each student and I have the best intentions, but there is not enough time." Laura expressed similar frustrations about the quantity of adaptations that needed to be made to the prescribed curriculum to ensure to meet her students' learning needs:

It was very challenging because you had to have different learning outcomes for many of the children and so you had to have a lot planned before hand so that way all children were able to be doing something during the day and learning and feeling successful so it was quite challenging to find different ways to make sure that all kids were [pause] it was just very challenging to make sure because all the children had different needs that needed to be met.

\section{Recommendations}

After describing their experiences in inclusive classrooms, participants were asked to give recommendations for teacher training institutions and to school boards. Consistent with the themes emerging from the data, the recommendations suggest a need for better training and support for new teachers so they are better able to manage the diverse needs in their classrooms. For a complete listing of recommendations, see Table 5. 


\section{Table 5}

\section{Recommendations}

1. To require longer practicums during teacher training to gain more supervised experience in classrooms.

2. To require more experience working with children with a diverse range of abilities (either in volunteer or paid work experiences) prior to entering teacher training programs.

3. To include in special education coursework the process of creating IEPs as well as referring to the IEP document on a continuous basis to inform student instruction and assessment. Also to include information specific to disabilities and the knowledge of where to look for more information.

4. To include coursework on classroom management strategies for a diverse range of students as part of teacher training.

5. To encourage practicing teachers with diverse experiences to talk to preservice teachers about the realities of inclusion.

6. To encourage teacher assistants and paraprofessionals to talk to preservice teachers about their roles and relationships with classroom teachers.

7. To include in methods courses examples of adaptations to instruction and lesson plans with a focus on diverse learners.

8. To include examples of alternative assessments in assessment coursework.

9. For school boards to create a mentorship program for new teachers. 


\section{Discussion}

Participants shared how they did not feel they were meeting the needs of the higher achieving students in their inclusive classrooms. Research focuses on schools not meeting the needs of gifted learners (Hughes, 1999; Renzulli \& Park, 2000; Robertson, 1991). In an action research study, Hughes (1999) outlined her concerns with the disproportionate quantity of services struggling students received and focused her research on how to best meet the needs of gifted students in her diverse classroom. She used surveys and interviews of students and parents to investigate how to meet the needs of her gifted students. She found that using a combination of strategies, including a balance between enrichment and acceleration, flexible grouping of students, and allowing students some autonomy in academic decision making, were perceived as effective in meeting these students' needs. Robertson (1991) found that one of the contributing factors for gifted students dropping out of high school was that teachers were not meeting these students' learning needs. The concern about not meeting the needs of their higher achieving students indicated by the group of new teachers interviewed in this study requires further investigation to determine the consistency of this concern across the province.

The new teachers reflected how they learned from other teachers with experience through a mentoring relationship. Extant literature describes the powerful role that mentoring can provide to teachers (Achinstein \& Barrett, 2004; Glazer, 2006; Smith, 2005). Achinstein and Barrett (2004) explain that "mentors offer novices a repertoire of frames to diagnose problems and develop alternative approaches to meet the needs of diverse students" (p. 717).

Participants also described how their students were experts about their own learning and needs. Although the idea of listening to students to inform ideas about educational policy is echoed throughout the literature (Cook-Sather, 2002; Corbett \& Wilson, 1995; Lincoln, 1995; Poplin \& Weeres, 1993; Schultz \& Cook-Sather, 2001) only recently, has there been research stating the need to include students to inform instruction (Cook-Sather, 2002, 2003). Cook-Sather (2003) states, "if we listen to the voices of our students to get the human dimension on how our practices ... affect people we can begin to make different decisions about how to ... support students' learning and learning differences" (p. 26). Through collaboration with their students, the new teachers were able to better understand and meet the learning needs of the students in their inclusive classrooms.

Participants perceived that social and behavioural considerations often overshadowed the academic curriculum. The participants reflected how they 
spent much of their instructional time engaged in classroom management. Achinstein and Barrett (2004) state that one of the biggest concerns new teachers report is classroom management. They argue that this is the result of one of two reasons. First, the authors argue that new teachers experience "practice shock" as they move from their ideals about teaching into the reality of the classroom. A second reason for the focus on behaviour concerns is that most often new teachers are placed in the most challenging teaching positions, including low socio-economic areas with high-risk students. They argue that new teachers often are faced with students that exhibit more extreme behaviours than more experienced teachers.

Based on their experiences, the participants recommended the need for knowledge and the need for experience. With the recognition that additional courses are not a practical addition to teacher training programs, participants explained that the need for knowledge could be addressed in previously existing coursework in the following areas: (a) special education (b) classroom management, (c) curriculum adaptations, and (d) assessment.

As well as knowledge, participants recommended that teacher training institutions should ensure that preservice teachers have the following experiences included in their teaching education programs: (a) work experience with a diverse range of children as a requirement to entering teaching training programs, (b) structured practicum experiences, and (c) learning from others with experience through guest speakers.

\section{Limitations of the Investigation}

Consistent with any research, there were limitations to this study. First, this study was limited to only seven new teachers in British Columbia. Although the participants taught in a range of locations in $\mathrm{BC}$, there are new teachers from areas of $\mathrm{BC}$ not represented in this study that may have had different experiences and would therefore have provided different recommendations.

Second, the participants who volunteered to share their experiences may only represent new teachers who felt comfortable sharing their experiences. Perhaps new teachers with more negative experiences may not have felt as comfortable to share their experiences.

While two out of the seven participants were from minority ethnic groups, there was little variation in age and the majority of participants came 
from middle class backgrounds. Only one of the participants was male. It would have been beneficial to develop an understanding of the experiences of new teachers with more diverse backgrounds, age, and sex to gain a more comprehensive understanding of the experiences of new teachers in inclusive classrooms.

Although it is not the authors' intent to generalize the results of this study to larger populations, certain findings of the study may reflect the experiences of other new teachers in inclusive classrooms. As such, it is important to discuss implications from the findings.

\section{Implications of the Study}

The needs of this group of new teachers as well as their initial recommendations for effective preservice teacher training have implications relating to three major groups of people: (a) new teachers, (b) teacher training institutions, and (c) school boards. These implications may also serve to guide future research on determining effective practice of training for teachers.

\section{Implications for New Teachers}

After completing their teacher training, new teachers should be willing to learn from others with experience, such as colleagues, parents, and students. If a mentorship program is not available in their district, new teachers should network to find someone they can rely on for advice and assistance. New teachers should collaborate with support staff and members of students' IEP teams to find the most effective ways to meet their students' needs. New teachers should be open to collaborating with parents about their child's needs. New teachers need to be willing to collaborate with their students to determine strategies that will help the students to be successful (Cook-Sather, 2003).

\section{Implications for Teacher Training Institutions}

Teacher training institutions have a responsibility to prepare preservice teachers with knowledge and experiences that will prepare them for their careers as teachers. The new teachers in this study voiced strong concerns about the knowledge and experiences they wish they had before they entered their inclusive classrooms. Teacher training institutions need to address the needs of new teachers to better prepare their preservice teachers (Brownell et al., 2005). Including the knowledge new teachers need in already existing coursework is a practical way to ensure preservice teachers are fully prepared for their 
first classrooms. Adjusting practicum lengths and times throughout the year will allow preservice teachers to observe a more realistic picture of what their own experiences may involve. Inviting practicing teachers, support staff, and paraprofessionals to speak to preservice teachers will also provide preservice teachers with the opportunity to learn from others' experiences.

\section{Implications for School Boards}

School boards need to consider implementing a mentorship program through which new teachers can be matched with an experienced teacher in a similar position. Mentorships provide invaluable learning experiences for new teachers during their first years (Whitaker, 2003). Providing this pair with release time from their classrooms to meet throughout the year will increase the likelihood of consistent meetings to discuss concerns as well as ensuring the program is not taxing on either the mentor or the new teacher.

\section{Directions for Further Research}

There are several directions for further research that emerge from this study. First, with a larger scale study employing a mixed method approach, results could be generalized to the larger body of new teachers in inclusive classrooms. Using the findings of the current study to inform a survey that a larger sample of new teachers could complete would provide stronger results to support the recommendations provided by this study. Variables such as grade level, number of students with special needs, severity of students' needs, and amount of classroom support should all be considered. Along with surveys, interviews with teachers as well as administrators, parents, and students could provide a more comprehensive account of the needs of new teachers to meet the diverse range of needs in an inclusive classroom.

Due to the findings that these new teachers were not able to meet the needs of all learners in their classrooms, especially the higher achieving students, future research should investigate ways to include increased opportunities for gifted and higher achieving students in inclusive classrooms. This research should include student input, parent input, and teacher perspectives.

It would be important for future research to situate new teachers' experiences in the current political initiatives that shape the delivery of service in special education. Specifically, research should investigate the effects of such initiatives on teachers' practice in inclusive classrooms.

Based on the recommendations outlined in this study, future research should investigate the effect of both increased knowledge and experiences in 
teacher training on the experiences of new teachers in inclusive classrooms. Related research could compare the experiences of new teachers involved in a mentoring program with those teachers who are not in a mentoring program.

\section{Summary}

This qualitative study employed a phenomenological approach to explore the experiences of new teachers in inclusive classrooms. With little available research in this area, this study begins to shed light on the issues and challenges new teachers face in their experiences in inclusive classrooms and provides initial recommendations that can help new teachers to meet the needs of the diverse learners in today's classrooms.

This study outlined the experiences a group of new teachers faced in their inclusive classrooms. This study also provided initial recommendations on how to prepare our new teachers for the realities of inclusive classrooms. Participants expressed the need for increased factual knowledge and experiences prior to entering their first teaching positions. A mentorship program for new teachers was also recommended. The initial recommendations have implications for new teachers, teacher training institutions, and school boards that should continue to be investigated.

This study provided areas for further research to continue to investigate what constitutes best practice of training for preservice teachers and how our new teachers may best be supported in their initial experiences teaching in inclusive classrooms.

Teaching in inclusive classrooms is a rewarding and challenging experience. Continued research is needed to ensure preservice teachers are given the knowledge and experiences that will best prepare them for the diversity that exists in today's inclusive classrooms. 


\section{References}

Achinstein, B. \& Barrett, A. (2004). (Re)framing classroom contexts: How new teachers and mentors view diverse learners and challenges of practice. Teachers College Record, 106, 716-746.

Alberta's Commission on Learning. (2004). Final report: Turning vision into a reality. Retrieved October 21, 2007, from

http://www.education.gov.ab.ca/commission/5_34.asp

Andrews, J., \& Lupart, J. (2000). The inclusive classroom: Educating exceptional children (2nd ed.). Scarborough, ON: Nelson Thomson Learning.

Billingsley, B. S. \& Tomchin, E. M. (1992). Four beginning LD teachers: What their experiences suggest for trainers and employers. Learning Disabilities Research and Practice, 7, 104-112.

Bondy, E., Ross, D., Sindelar, P., \& Griffin, C. (1995). Elementary and special educators learning to work together: Team building processes. Teacher Education and Special Education, 18, 91-102.

Brantlinger, E., Jimenez, R., Klingner, J., Pugach, M., \& Richardson, V. (2005). Qualitative studies in special education. Exceptional Children, 71, 195207.

BC College of Teachers. (2004). Standards for the education, competence, and professional conduct of educators in BC. Retrieved February 16, 2005 from http://www.bcct.ca/standards/default.aspx

BC Confederation of Parent Advisory Councils. (1999). Executive summary. In Special Education Review in Public Education. Retrieved November 23, 2004, from http://www. bccpac.ca/resources/papers/specialedreview99.htm

BC Ministry of Education. (1996). RSBC School Act. In Manual of School Law, K-12. Retrieved July 21, 2005, from http://www.bced.gov.bc.ca/legislation/schoollaw/

BC Ministry of Education. (2000). A review of special education in BC. Retrieved February 12, 2005, from http://www.bced.gov.bc.ca/specialed/review/report/

BC Ministry of Education. (2001). Special education. Retrieved June 7, 2005, from http://www.bced.gov.bc.ca/specialed/ 
BC Ministry of Education. (2006). Special education. Retrieved October 21, 2007, from http://www.bced.gov.bc.ca/specialed/

BC Ministry of Education, Skills, and Training. (1997). Addressing student differences: Next steps. Victoria, BC: Queen's Printer.

BC Ministry of Finance and Corporate Relations. (2000). BC stats: Earnings and employment trends April 2000. Retrieved October 21, 2007, from http://www.bcstats.gov.bc.ca/ pubs/eet/eet0004.pdf

Brownell, M. T., Ross, D. D., Colon, E. P., \& McCallum, C. L. (2005). Critical features of special education teacher preparation: A comparison with general teacher education. The Journal of Special Education, 38, 242252.

Colaizzi, P. F. (1978). Psychological research as the phenomenologist views it, in R. Valle, \& M. Kings (Eds.), Existential phenomenological alternatives for psychology. New York: Oxford University Press, 48-71.

Cook, B. G. (2002). Inclusive attitudes, strengths, and weaknesses of preservice general educators enrolled in a curriculum infusion teacher preparation program. Teacher Education and Special Education, 25, 262-277.

Cook-Sather, A. (2002). Authorizing students' perspectives: Toward trust, dialogue, and change in education. Educational Researcher, 31, 3-14.

Cook-Sather, A. (2003). Listening to students about learning differences. Exceptional Children, 35, 22-26.

Corbett, D., \& Wilson, B. (1995). Make a difference with, not for, students: A plea to researchers and reformers. Educational Researcher, 24, 12-17.

Creswell, J. W. (1998). Qualitative inquiry and research design: Choosing among five traditions. Thousand Oaks, CA: Sage Publications, Inc.

Creswell, J. W. (2003). Research design: Qualitative, quantitative, and mixed methods approaches $\left(2^{\text {nd }}\right.$ ed.). Thousand Oaks, CA: Sage Publications, Inc.

Davern, L. (1999). Parents' perspectives on personnel attitudes and characteristics in inclusive school settings: Implications for teacher preparation programs. Teacher Education and Special Education, 22, 165-182.

Glazer, E. M. (2006). The collaborative apprenticeship model: Situated professional development within school settings. Teaching and Teacher Education, 22, 179-193. 
Hamre, B., \& Oyler, C. (2004). Preparing teachers for inclusive classrooms: Learning from a collaborative inquiry group. Journal of Teacher Education, 55, 154-163.

Hughes, L. (1999). Action research and practical inquiry: How can I meet the needs of the high-ability student within my regular education classroom. Journal for the Education of the Gifted, 22, 282.

Kilgore, K. L. \& Griffin, C. C. (1998). Beginning special educators: Problems of practice and the influence of school context. Teacher Education and Special Education, 21, 155-173.

Lincoln, Y. (1995). In search of students' voices. Theory Into Practice, 34, 88-93.

Lombardi, T. P., \& Hunka, N. J. (2001). Preparing general education teachers for inclusive classrooms: Assessing the process. Teacher Education and Special Education, 24, 183-197.

Malaspina University College. (2004). University degree completion and transfer programs. Retrieved February 20, 2005, from Malaspina University College, Faculty of Education Web site: http://www.mala.ca/calendar/UNIVEDUC.asp

Moustakas, C. (1994). Phenomenological research methods. Thousand Oaks, CA: Sage Publications, Inc.

Naylor, C. (2002). BC teachers' views of special education issues. In British Columbia Teachers' Federation research report: Worklife of teachers survey series. Retrieved October 21, 2007, from www.bctf.ca/publications/ResearchReports.aspx $\mathrm{id}=5558$

Naylor, C. (2004). How teachers in Coquitlam and Nanaimo view special education and ESL services. In British Columbia Teachers' Federation research report: Teaching in 2003 survey report. Retrieved February 12, 2005, from http://www.bctf.ca/Education/Inclusive Ed/ResearchProject/ dc/SurveyReport.html

Patton, M. Q. (1990). Qualitative evaluation and research methods (2nd ed.). Newbury Park, CA: Sage Publications, Inc.

Polkinghorne, D. E. (1989). Phenomenological research methods. In R. S. Valle \& S. Halling (Eds.), Existential-phenomenological perspectives in psychology (pp. 41-60). New York: Plenum Press.

Poplin, M., \& Weeres, J. (1993). Listening at the learner's level. The Executive Educator, 15, 14-19. 
Renzulli, J. S. \& Park, S. (2000). Gifted dropouts: The who and the why. Gifted Child Quarterly, 44, 261-271.

Roberts, J. \& Cairns, K. (1999). School children with HIV/AIDS. Calgary, AB: Detselig Enterprises Ltd.

Robertson, E. (1991). Neglected dropouts: The gifted and talented. Equity and Excellence, 25, 62-74.

Schultz, J., \& Cook-Sather, A. (2001). In our own words: Students' perspectives on school. Lanham, MD: Rowman \& Littlefield Publishers, Inc.

Seidman, I. (1998). Interviewing as qualitative research: A guide for researchers in education and social sciences ( $2^{\text {nd }}$ ed.). New York: Teachers College Press.

Simon Fraser University. (2004). Bachelor of education requirements. Retrieved February 20, 2005, from Simon Fraser University, Faculty of Education Web site:

http://www.educ.sfu.ca/ugradprogs/academic_programs/degrees/bed.html

Smith, M. V. (2005). Modern mentoring: Ancient lessons for today. Music Educator's Journal, 92, 62.

Strawderman, C., \& Lindsey, P. (1995). Keeping up with the times: Reform in teacher education. Journal of Teacher Education, 46, 95-100.

Trinity Western University. (2004). Concurrent five-year B.A./B.Ed. or B.Sc./ B.Ed. program graduation requirements. Retrieved February 20, 2005, from Trinity Western University School of Education Web site: http://www.twu.ca/academics/education/ concurrent-fact-sheet-october-2007.pdf

University of British Columbia. (2004). Teacher education: Bachelor of education program. Retrieved February 20, 2005, from University of British Columbia, Faculty of Education Web site: www.educ.ubc.ca

University College of the Cariboo. (2004). Bachelor of education courses: Year two. Retrieved February 20, 2005, from University College of the Cariboo, School of Education Web site:

http://www.cariboo.bc.ca/education/bed/courses/year2.html

University of Northern British Columbia. (2004). Early years program requirements. Retrieved February 20, 2005, from University of Northern British Columbia, Education Program Web site: http:/www.unbc.ca/education/ 
University of Victoria. (2003). Elementary professional degree program: Program outline. Retrieved February 20, 2005, from University of Victoria, Faculty of Education Web site: http://www.educ.uvic.ca/ete/profout.htm

Welch, M. (1996). Teacher education and the neglected diversity: Preparing educators to teach students with disabilities. Journal of Teacher Education, 47, 355-366.

Werts, M. G., Mamlin, N., \& Pogoloff, S. M. (2002). Knowing what to expect: Introducing preservice teachers to IEP meetings. Teacher Education and Special Education, 25, 413-418.

Whitaker, S. D. (2000). What do first-year special education teachers need? Teaching Exceptional Children, 33, 28-36.

Whitaker, S. D. (2003). Needs of beginning special education teachers: Implications for teacher education. Teacher Education and Special Education, 26, 106-117.

Wigle, S. E., Wilcox, D. J. (1996). Inclusion: Criteria for the preparation of education personnel. Remedial and Special Education, 17, 323-328.

\section{Authors' Note}

Correspondence concerning this article should be addressed to Jessie Moore, 2150 Kings Road, Victoria, BC, V8R 2P9. Email: jessielo@uvic.ca. 